\title{
Spatial and temporal patterns of ciliate species composition (Protozoa: Ciliophora) in the plankton of the Upper Paraná River floodplain
}

\author{
Pauleto, GM. ${ }^{\mathrm{a}, \mathrm{b}}$, Velho, LFM. ${ }^{\mathrm{a} b *}$, Buosi, PRB. ${ }^{\mathrm{a}}$, \\ Brão, AFS. ${ }^{\mathrm{a}}$ Lansac-Tôha, FA. ${ }^{\mathrm{a}, \mathrm{b}}$ and Bonecker, $C C^{\mathrm{a}}{ }^{\mathrm{a}, \mathrm{b}}$ \\ ${ }^{a}$ Núcleo de Pesquisas em Limnologia, Ictiologia e Aquicultura - Nupélia, \\ Universidade Estadual de Maringá - UEM, \\ Av. Colombo, 5790, CEP 87020-900, Maringá, PR, Brazil \\ 'Programa de Pós-graduação em Ecologia de Ambientes Aquáticos Continentais, \\ Universidade Estadual de Maringá - UEM \\ Av. Colombo, 5790, CEP 87020-900, Maringá, PR, Brazil \\ *e-mail: felipe@nupelia.uem.br
}

Received November 11, 2008 - Accepted March 30, 2008 - Distributed June 30, 2009

(With 6 figures)

\begin{abstract}
Spatial and temporal patterns of plankton ciliates species composition in the Paraná River floodplain were investigated. Samplings were carried out in twelve environments in two distinct hydrological periods (limnophase and potamophase). A total of 61 species of ciliates were recorded, and among them 21 are classified as pelagic while 40 are considered preferentially as littoral species. The registered species belong to eleven orders, and among them, Prostomatida was the most specious followed by Hymenostomatida and Peritrichida. The ciliate species composition was significantly distinct between periods, but not among environments. In this way, typically pelagic species characterized the ciliate community during the limnophase period, while the littoral species were predominant during the potamophase period. Our results strongly support the idea of the flood pulse as the main factor driving the composition pattern of the planktonic ciliates community in the Paraná River floodplain.
\end{abstract}

Keywords: planktonic ciliates, species composition, floodplain, Paraná River.

\section{Padrões espaciais e temporais da composição de espécies de ciliados (Protozoa: Ciliophora) no plâncton da planície de inundação do Alto Rio Paraná}

\begin{abstract}
Resumo
No presente estudo foram investigados os padrões espaciais e temporais da composição de espécies de ciliados planctônicos na planície de inundação do Alto Rio Paraná. As amostras foram obtidas em 12 ambientes, em dois períodos hidrológicos distintos (limnofase e potamofase). Foram registradas 61 espécies de ciliados entre as quais 21 foram classificadas como pelágicas enquanto 40 foram consideradas preferencialmente litorâneas. As espécies registradas pertencem a 11 ordens, sendo Prostomatida foi a mais especiosa, seguida por Hymenostomatida e Peritrichida. A composição de espécies de ciliados foi significativamente distinta entre os períodos hidrológicos, enquanto que entre os ambientes, diferenças na composição não foram evidenciadas. Dessa forma, espécies tipicamente pelágicas caracterizaram a comunidade de ciliados na limnofase, enquanto que espécies litorâneas foram preponderantes para a composição de ciliados na potamofase. Os resultados suportam a idéia do pulso de inundação como principal fator controlador dos padrões de composição da comunidade de ciliados planctônicos na planície de inundação do Alto Rio Paraná.
\end{abstract}

Palavras-chave: ciliados planctônicos, composição de espécies, planície de inundação, Rio Paraná. 


\section{Introduction}

Due to their fluvial dynamics, floodplains are characterized by the presence of several water bodies, with a high diversity of lotic, lentic and semi-lotic environments, that should be integrally analyzed, as an unit denominated the "river-floodplain system" (Junk et al., 1989). The seasonal alternation between the dry and the flood periods establishes a particular environmental situation characterized by "hydrological pulses" (Neiff, 1990). Because of this high level of spatial and temporal heterogeneity, floodplains have one of the highest levels of biodiversity among the known aquatic environments. The connectivity among the environment must be considered as an essential factor that strongly contributes to the spatial and temporal dynamic of these ecosystems (Ward et al., 1999).

In the Upper Paraná River floodplain, studies of the biodiversity and different ecological aspects of many aquatic communities, including planktonic communities, have been performed over several years (Lansac-Tôha et al., 2009). These studies demonstrated the relevance of the flood pulse and the hydrological connectivity on the communities' structures. However, surveys of the biodiversity and ecology of protozoa ciliates are still scarce in the Neotropical region, especially in the floodplain systems.

Protozoans play a relevant role in the metabolism of aquatic ecosystems. According to Finlay and Esteban (1998), the predation of protozoans on the other microorganisms stimulates the microbial community, and increases the nutrients cycling that would otherwise remain in the bacterial biomass. Considering the seasonal succession of the plankton community, the ciliates are efficient predators of the phytoplankton (Schweizer, 1997), acting as competitors to the rotifers and microcrustaceans, though these protozoans are also consumed by these predators of larger body size (Müller et al., 1991).

The trophic state is essential for the determination of the pattern of variation in the spatial and temporal distribution of planktonic ciliates (Velho et al., 2005). In the lotic environments, the flushing rate is a central factor affecting the organization of aquatic communities. Seasonal changes in this discharge regime play an important function, structuring the ciliates assemblages and determining their role in the trophic food web (PrimcHabdija et al., 1998; Bereczky, 1998).

This study analyzed the variation in the species composition during distinct hydrological periods (limnophase or lower water period, and potamophase or high water period) and environments (lakes, rivers and channels) in the Upper Paraná River floodplain. Additionally, this study emphasized the relative importance of flood pulse, connectivity and hydrodynamics as driving the patterns of ciliates species composition.

\section{Material and Methods}

\subsection{Study area}

The study was performed in twelve environments in the Upper Paraná River floodplain ( $22^{\circ} 40^{\prime}-22^{\circ} 50^{\prime} \mathrm{S}$ and $53^{\circ} 10^{\prime}-53^{\circ} 40^{\prime} \mathrm{W}$ ), belonging to Paraná, Baía and Ivinheima systems. Within each system, four environments were selected, including the main river, a closed lake, an open lake and a channel (see Figure 1).

The Paraná system consists of the Paraná River and associated floodplain lakes in the islands and "várzea". The stretch of this river that was studied presents a braided channel, with mean current flow relatively high, varied width and extensive islands and lateral bars. In this stretch, the river is $4.0 \mathrm{~m}$ in mean depth, and it can reach a maximum depth of $15.0 \mathrm{~m}$ (Thomaz et al., 1992). In this system, we collected samples in the Paraná River, Cortado channel, Garças (open lake) and Osmar (closed lake), see Figure 1.

The Baía system encompasses the Baía River and several associated lakes along its course, and it is connected to Paraná River through a channel in its lower portion. This sinuous river presents varied width, a mean depth of $3.2 \mathrm{~m}$, low declivity and low current flow, and is directly influenced by the hydrological regime of Paraná River (Thomaz et al., 1991) In this system, we collected samples in the Baía River, Curutuba Channel, Guaraná (open lake) and Fechada (closed lake), see Figure 1.

The Ivinheima system is formed by the Ivinheima River and floodplain lakes associated with this river, which is one of the main tributaries located at the right bank of the Paraná River. It has a mean depth of $3.9 \mathrm{~m}$. It presents turbulent waters and runs parallel to the Paraná River in its lower stretch. It is connected to the Baía River through the Curutuba River, and to the Paraná River through the Ipoitã Channel and two other channels (Thomaz et al., 1992). In this system, we collected samples in the Ivinheima, Ipoitã channel, Patos (open lake) and Ventura (closed lake), see Figure 1.

\subsection{Sampling and laboratory analysis}

Samplings were carried out in February 2007 (potamophase period) and August 2007 (limnophase period). Samples (2 L) were taken in triplicate in the pelagic zone from each environment using the Van Dorn bottle. The material was stored in plastic flasks and transported to the laboratory where it was concentrated via a plankton net $(10 \mu \mathrm{m})$. The ciliates were analyzed in vivo, within a maximum period of 6 hours after the sampling, using an optical microscope (Olympus CX-41), based mainly on the work Foissner and Berger (1996) and Foissner et al. (1999).

\subsection{Data analyses}

In order to estimate the ciliate species richness and analyze which portion of the expected total species richness was recorded in the present survey, different nonparametric extrapolating indices based on incidence 


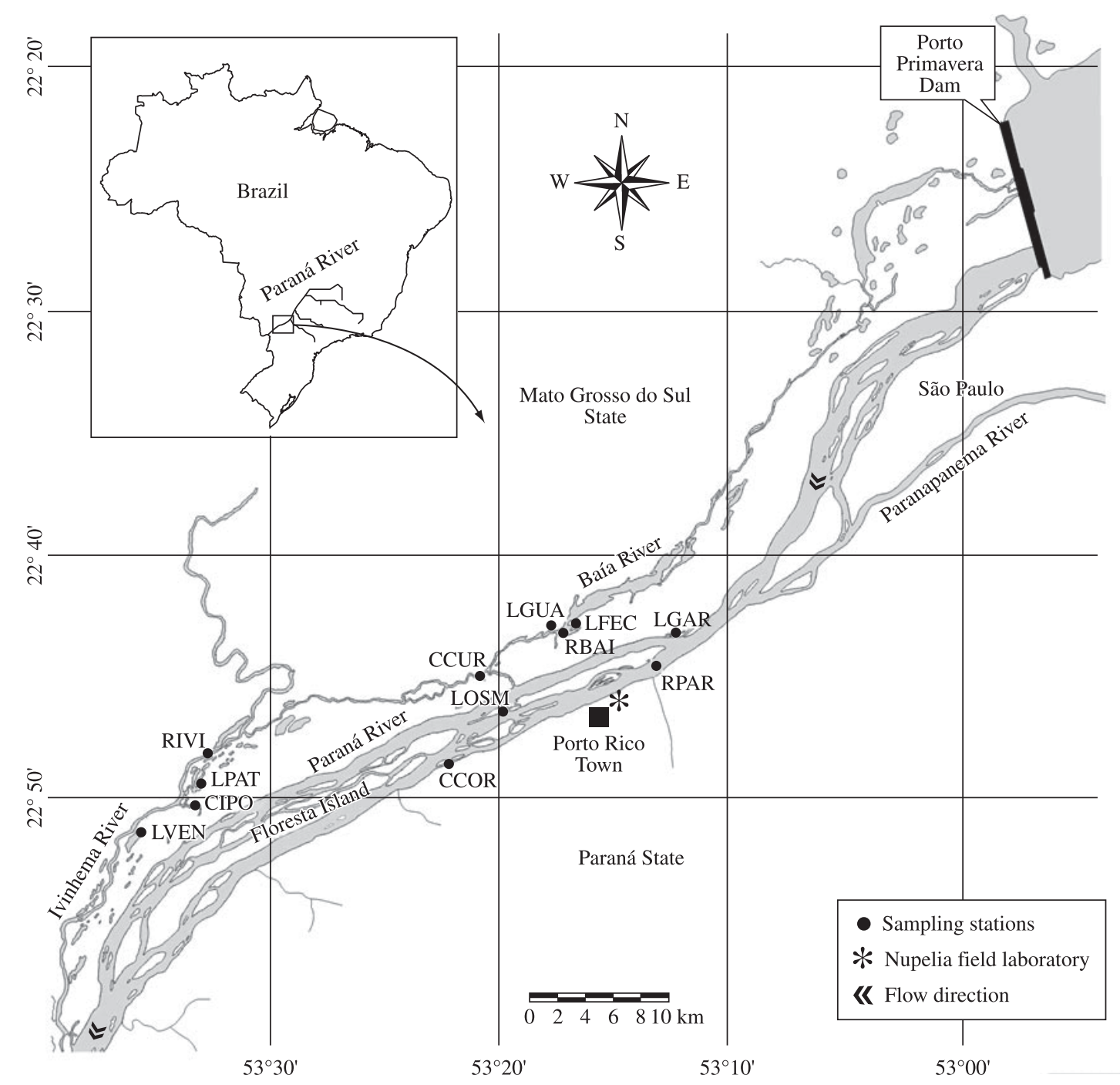

Figure 1. Study area with the location of the sampling stations. Paraná River (RPAR); Baía River (RBAI); Ivinheima River (RIVI); Ipoitã Channel (CIPO); Curutuba Channel (CCUR); Cortado Channel (CCOR); Garças Lake (LGAR); Patos Lake (LPAT); Fechada Lake (LFEC); Guaraná Lake (LGUA); Ventura Lake (LVEN) and Osmar Lake (LOSM).

data were used. Jacknife1 and 2, and Bootstrap estimators were used, and the calculation was done using the EstimateS software (Colwell, 2006).

The classification of pelagic and littoral species was done according to Berger and Foissner (2003). The occurrence frequency of a particular species was calculated as the percentage of samples in which the species occurs $(F r=n * 100 / N$, where $n=$ occurrences of the species in the analyzed samples and $N=$ total number of analyzed samples). According to this occurrence, the species were classified into the four proposed groups as follows: constant species (i.e. occurring in $76-100 \%$ of the samples), frequent species (i.e. occurring in 51-75\%), accessory species (i.e. occurring in $26-50 \%$ of the samples), and accidental species (i.e. occurring in below $25 \%$ of the samples).
Detrended Correspondence Analysis (DCA) (Hill and Gauch, 2004) was performed to summarize changes in the ciliates composition among the environments and between the hydrological periods. This analysis was carried out using the PC-ORD software (version 4.1; McCune and Mefford, 1999).

Aiming to quantify the alterations in the ciliate species composition between the hydrological periods and in the several environment types, the Beta $(\beta-1)$ index was estimated (Harrison et al., 1992) through the following expression:

$\beta-1=\{[(\mathrm{S} / \alpha)-1] /(\mathrm{N}-1)\} \times 100$

where $\mathrm{S}$ is the total number of ciliate species recorded at each environment type; $\alpha$ is the mean number of species 
Table 1. Faunistic survey of ciliate species recorded in the different types of environments and periods in the Upper Paraná River floodplain. $(\mathrm{H}=$ Habitat; $\mathrm{P}=$ pelagic species and $\mathrm{L}=$ littoral species) $(\mathrm{Ri}=$ Rivers, $\mathrm{Ch}=\mathrm{Channels}$; $\mathrm{OL}=\mathrm{Open}$ lakes; $\mathrm{CL}=$ Closed lakes) $($ Code $=$ codes used in DCA analysis $)$. Constancy index:

\begin{tabular}{|c|c|c|c|c|c|c|c|c|c|c|}
\hline \multirow[t]{2}{*}{ Species } & \multicolumn{5}{|c|}{ Potamophase } & \multicolumn{5}{|c|}{ Limnophase } \\
\hline & H & $\mathbf{R i}$ & Ch & OL & $\mathbf{C L}$ & $\mathbf{R i}$ & Ch & OL & $\mathbf{C L}$ & Code \\
\hline \multicolumn{11}{|l|}{ COLPODIDA } \\
\hline Colpoda steinii Maupas, 1883 & $\mathrm{P}$ & & & & & & & & & Cst \\
\hline Cyrtolophosis mucicola Stokes, 1885 & $\mathrm{~L}$ & & & & & & & & & $\mathrm{Cmu}$ \\
\hline \multicolumn{11}{|l|}{ HAPTORIDA } \\
\hline Actinobolina sp. & $\mathrm{P}$ & & & & & & & & & Act \\
\hline $\begin{array}{l}\text { Askenasia volvox } \\
\text { (Eichwald, 1852) Kahl, } 1930\end{array}$ & $\mathrm{P}$ & & & & & & & & & Avo \\
\hline $\begin{array}{l}\text { Lacrymaria olor } \\
\text { (Mueller, 1786) }\end{array}$ & & & & & & & & & & \\
\hline Bory Saint-Vincent, 1824 & $\mathrm{~L}$ & & & & & & & & & Lol \\
\hline Lagynophrya acuminata Kahl, 1935 & $\mathrm{P}$ & & & & & & & & & $\mathrm{Lac}$ \\
\hline $\begin{array}{l}\text { Mesodinium pulex } \\
\text { (Clap. and Lach., 1859) Stein, } 1867\end{array}$ & $\mathrm{P}$ & & & & & & & & & $\mathrm{Mpu}$ \\
\hline $\begin{array}{l}\text { Paradileptus ellephantinus } \\
\text { (Svec, 1897) Kahl, } 1931\end{array}$ & $\mathrm{P}$ & & & & & & & & & Pel \\
\hline Spathidium sp. & $\mathrm{L}$ & & & & & & & & & Spa \\
\hline \multicolumn{11}{|l|}{ HETEROTRICHIDA } \\
\hline Spirostomum minus Roux, 1901 & $\mathrm{~L}$ & & & & & & & & & Smi \\
\hline Stentor muelleri Ehrenb., 1831 & $\mathrm{~L}$ & & & & & & & & & Smu \\
\hline $\begin{array}{l}\text { Stentor niger } \\
\text { (Mueller, 1773) Ehrenb., } 1831\end{array}$ & $\mathrm{~L}$ & & & & & & & & & Sni \\
\hline Stentor roeselii Ehrenb., 1835 & $\mathrm{~L}$ & & & & & & & & & Sro \\
\hline \multicolumn{11}{|l|}{ HYMENOSTOMATIDA } \\
\hline $\begin{array}{l}\text { Dexiotricha granulosa } \\
\text { (Kent, 1881) Foissner et al., } 1994\end{array}$ & $\mathrm{~L}$ & & & & & & & & & Dgr \\
\hline $\begin{array}{l}\text { Disematostoma buetschilii } \\
\text { Lauterborn, } 1894\end{array}$ & $\mathrm{P}$ & & & & & & & & & $\mathrm{Dbu}$ \\
\hline $\begin{array}{l}\text { Frontonia acuminate } \\
\text { (Ehrenb., 1833) Buetschilii, } 1889\end{array}$ & $\mathrm{~L}$ & & & & & & & & & $\mathrm{Fac}$ \\
\hline $\begin{array}{l}\text { Frontonia atra } \\
\text { (Kahl, 1931) Buetschilii, } 1889\end{array}$ & $\mathrm{~L}$ & & & & & & & & & Fat \\
\hline $\begin{array}{l}\text { Lembadion lucens } \\
\text { (Maskell, 1887) Kahl, } 1931\end{array}$ & $\mathrm{~L}$ & & & & & & & & & Llu \\
\hline $\begin{array}{l}\text { Paramecium bursaria } \\
\text { (Ehrenb., 1831) Focke, } 1836\end{array}$ & $\mathrm{~L}$ & & & & & & & & & $\mathrm{Pbu}$ \\
\hline Stokesia vernalis Wenrich, 1929 & $\mathrm{P}$ & & & & & & & & & Sve \\
\hline $\begin{array}{l}\text { Tetrahymena pyriformis } \\
\text { Ehrenb., } 1830\end{array}$ & $\mathrm{~L}$ & & & & & & & & & Tpy \\
\hline \multicolumn{11}{|l|}{ HYPOTRICHIDA } \\
\hline $\begin{array}{l}\text { Aspidisca cicada } \\
\text { (Mueller, 1786) Clap. and Lach., } 1858\end{array}$ & $\mathrm{~L}$ & & & & & & & & & Aci \\
\hline $\begin{array}{l}\text { Aspidisca lynceus } \\
\text { (Mueller, 1773) Ehrenb., } 1830\end{array}$ & $\mathrm{~L}$ & & & & & & & & & Aly \\
\hline Holosticha monilata Kahl, 1928 & $\mathrm{~L}$ & & & & & & & & & Hmo \\
\hline Oxytricha sp. & $\mathrm{L}$ & & & & & & & & & Oxy \\
\hline
\end{tabular}


Table 1. Continued...

\begin{tabular}{|c|c|c|c|c|c|c|c|c|c|c|}
\hline \multirow[t]{2}{*}{ Species } & \multicolumn{5}{|c|}{ Potamophase } & \multicolumn{5}{|c|}{ Limnophase } \\
\hline & $\mathbf{H}$ & $\mathbf{R i}$ & Ch & OL & CL & $\mathbf{R i}$ & Ch & OL & CL & Code \\
\hline $\begin{array}{l}\text { Stichotricha aculeata } \\
\text { Wrzesniowski, } 1886\end{array}$ & $\mathrm{~L}$ & & & & & & & & & $\mathrm{Sac}$ \\
\hline KARIORELICTIDA & & & & & & & & & & \\
\hline Loxodes magnus Stokes, 1887 & $\mathrm{~L}$ & & & & & & & & & Lma \\
\hline OLIGOTRICHIDA & & & & & & & & & & \\
\hline $\begin{array}{l}\text { Codonella cratera } \\
\text { (Leidy, 1877) Imhof, } 1885\end{array}$ & $\mathrm{P}$ & & & & & & & & & Cer \\
\hline $\begin{array}{l}\text { Halteria grandinella } \\
\text { (Mueller, 1773) Dujardin, } 1841\end{array}$ & $\mathrm{P}$ & & & & & & & & & Hgr \\
\hline Limnostrombidium sp. & $\mathrm{P}$ & & & & & & & & & Lim \\
\hline $\begin{array}{l}\text { Rimostrombidium humile } \\
\text { (Penard, 1922) Petz and Foissner, } 1992\end{array}$ & $\mathrm{P}$ & & & & & & & & & Rhu \\
\hline $\begin{array}{l}\text { Rimostrombidium lacustris } \\
\text { (Foissner et al., 1988) } \\
\text { Petz and Foissner, } 1992\end{array}$ & $\mathrm{P}$ & & & & & & & & & Rla \\
\hline $\begin{array}{l}\text { Tintinnidium fluviatile } \\
\text { (Stein, 1863) Kent, } 1881\end{array}$ & $\mathrm{P}$ & & & & & & & & & Tfl \\
\hline Tintinnidium $\mathrm{sp}$. & $\mathrm{P}$ & & & & & & & & & Tin \\
\hline PERITRICHIDA & & & & & & & & & & \\
\hline $\begin{array}{l}\text { Campanella umbellaria } \\
\text { (Linn., 1758) Goldfuss, } 1820\end{array}$ & $\mathrm{~L}$ & & & & & & & & & Cum \\
\hline $\begin{array}{l}\text { Epicarchesium pectinatum } \\
\text { Zacharias, } 1897\end{array}$ & $\mathrm{P}$ & & & & & & & & & Epe \\
\hline Epistylis coronata Nusch, 1970 & $\mathrm{~L}$ & & & & & & & & & Eco \\
\hline Epistylis pygmauem Ehrenb., 1838 & $\mathrm{P}$ & & & & & & & & & Epy \\
\hline $\begin{array}{l}\text { Opercularia nutans } \\
\text { (Ehrenb., 1831) Stein, } 1854\end{array}$ & $\mathrm{~L}$ & & & & & & & & & Onu \\
\hline $\begin{array}{l}\text { Pseudovorticella chlamydophora } \\
\text { (Penard, 1922) Jankowski, } 1976\end{array}$ & $\mathrm{~L}$ & & & & & & & & & Pch \\
\hline Vorticella aquadulcis Stokes, 1885 & $\mathrm{~L}$ & & & & & & & & & Vaq \\
\hline Vorticella campanula Ehrenb., 1831 & $\mathrm{~L}$ & & & & & & & & & Vca \\
\hline PLEUROSTOMATIDA & & & & & & & & & & \\
\hline $\begin{array}{l}\text { Litonotus lamella } \\
\text { (Mueller, 1773) Foissner et al., } 1995\end{array}$ & $\mathrm{~L}$ & & & & & & & & & Lla \\
\hline PROSTOMATIDA & & & & & & & & & & \\
\hline $\begin{array}{l}\text { Balanion planctonicum } \\
\text { Foissner et al., } 1994\end{array}$ & $\mathrm{P}$ & & & & & & & & & Bpl \\
\hline Bursellopsis sp. & $\mathrm{P}$ & & & & & & & & & Bur \\
\hline $\begin{array}{l}\text { Bursellopsis spumosa } \\
\text { (Schmidt, 1920) Corliss, } 1960\end{array}$ & $\mathrm{P}$ & & & & & & & & & Bsp \\
\hline Coleps elongatus Ehrenb., 1831 & $\mathrm{~L}$ & & & & & & & & & Cel \\
\hline $\begin{array}{l}\text { Coleps hirtus } \\
\text { (Mueller, 1786) Nitzsch, } 1827\end{array}$ & $\mathrm{~L}$ & & & & & & & & & Chi \\
\hline Coleps sp. & $\mathrm{L}$ & & & & & & & & & Col \\
\hline Enchelys sp. & $\mathrm{L}$ & & & & & & & & & Enc \\
\hline Holophrya discolor Ehrenb., 1833 & $\mathrm{~L}$ & & & & & & & & & Hdi \\
\hline Holophrya ovum Ehrenb., 1831 & $\mathrm{~L}$ & & & & & & & & & Hov \\
\hline
\end{tabular}


Table 1. Continued...

\begin{tabular}{|c|c|c|c|c|c|c|c|c|c|c|}
\hline \multirow[t]{2}{*}{ Species } & \multicolumn{5}{|c|}{ Potamophase } & \multicolumn{5}{|c|}{ Limnophase } \\
\hline & $\mathbf{H}$ & $\mathbf{R i}$ & Ch & $\mathbf{O L}$ & $\mathbf{C L}$ & $\mathbf{R i}$ & Ch & OL & $\mathbf{C L}$ & Code \\
\hline $\begin{array}{l}\text { Holophrya teres } \\
\text { (Ehrenb., 1833) Foissner et al., } 1994\end{array}$ & $\mathrm{~L}$ & & & & & & & & & Hte \\
\hline $\begin{array}{l}\text { Urotricha farcta } \\
\text { Clap. and Lach., } 1859\end{array}$ & $\mathrm{~L}$ & & & & & & & & & Ufa \\
\hline Urotricha sp. & $\mathrm{P}$ & & & & & & & & & Uro \\
\hline SCUTICOCILIATIDA & & & & & & & & & & \\
\hline $\begin{array}{l}\text { Calyptotricha lanuginosa } \\
\text { (Penard, 1922) } \\
\text { Wilbert and Foissner, } 1980\end{array}$ & $\mathrm{~L}$ & & & & & & & & & $\mathrm{Cla}$ \\
\hline $\begin{array}{l}\text { Cinetochilum margaritaceum } \\
\text { (Ehrenb., 1831) Perty, } 1849\end{array}$ & $\mathrm{~L}$ & & & & & & & & & $\mathrm{Cma}$ \\
\hline $\begin{array}{l}\text { Ctedoctema acanthocryptum } \\
\text { Stokes, } 1884\end{array}$ & $\mathrm{~L}$ & & & & & & & & & $\mathrm{Cac}$ \\
\hline Cyclidium glaucoma Mueller, 1773 & $\mathrm{~L}$ & & & & & & & & & $\mathrm{Cgl}$ \\
\hline $\begin{array}{l}\text { Cyclidium heptatricum } \\
\text { Schewiakoff, } 1893\end{array}$ & $\mathrm{~L}$ & & & & & & & & & Che \\
\hline Pleuronema cf. smalli Dragesco, 1968 & $\mathrm{~L}$ & & & & & & & & & Psm \\
\hline Frequent & Aces & & & ccide & & & ack & & & \\
\hline
\end{tabular}

found in the samples; and $\mathrm{N}$ is the number of sampling units.

A Cluster Analysis (expressed by a dendrogram) based on the Jaccard index was carried out to verify the similarity of the ciliates species composition among the environment types and between periods. The Cophenetic Correlation Coefficient was calculated to estimate how much the dendrogram represented the original data.

Finally, in order to test the statistical significance of the differences in the distribution of scores from the different periods and environments derived from a DCA, we performed an ANOVA (Statsoft, 2000), considering $\mathrm{p}<0.05$ as significant

\section{Results}

Considering both periods and environments, 61 ciliate species were identified (as shown in Table 1). The results from the non-parametric extrapolating index demonstrated that the observed richness represented between 71 and $91 \%$ of the estimated richness. Bootstrap (67 species) was the extrapolating index that best reflected the observed richness (see Figure 2).

Among the 61 identified species, 18 species were recorded only during the potamophase and 11 species were found only during the limnophase (as shown in Table 1). Fourteen species occurred exclusively in lentic environments, while six species were registered only in lotic ones.

The ciliates species found belong to 11 orders, and among them, Prostomatida presented a higher number of species (12 species), followed by Hymenostomatida and
Peritrichida (8 species each), as well as Oligotrichida and Haptorida (7 species each), as shown in Table 1.

Considering the different environments and periods, Oligotrichida and Prostomatida show a higher species richness. Peritrichida presented a high species richness especially in the rivers; Scuticociliatida presented, in general, a high number of species in lotic environments (rivers and channels); Haptorida was important in channels in both periods and in the closed lakes during limnophase; and Hymenostomatida present high species richness only in the closed lakes during the potamophase (see Figure 3).

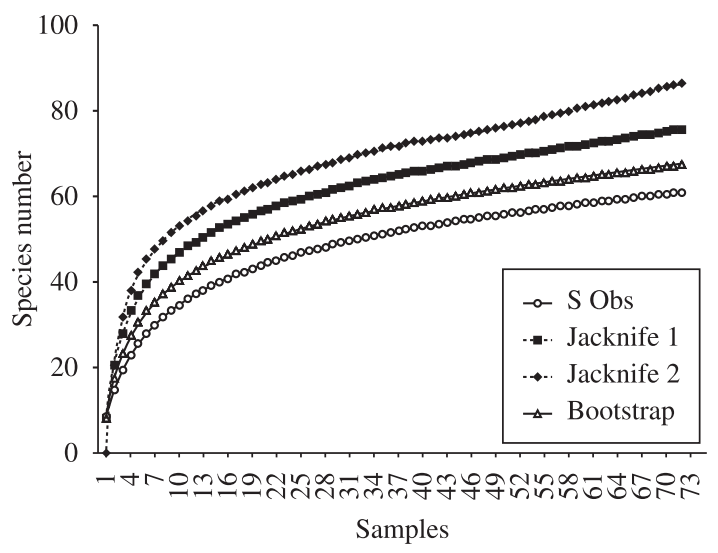

Figure 2. Results from the non-parametric extrapolating index of the species richness of planktonic ciliates in the Upper Paraná River floodplain. 

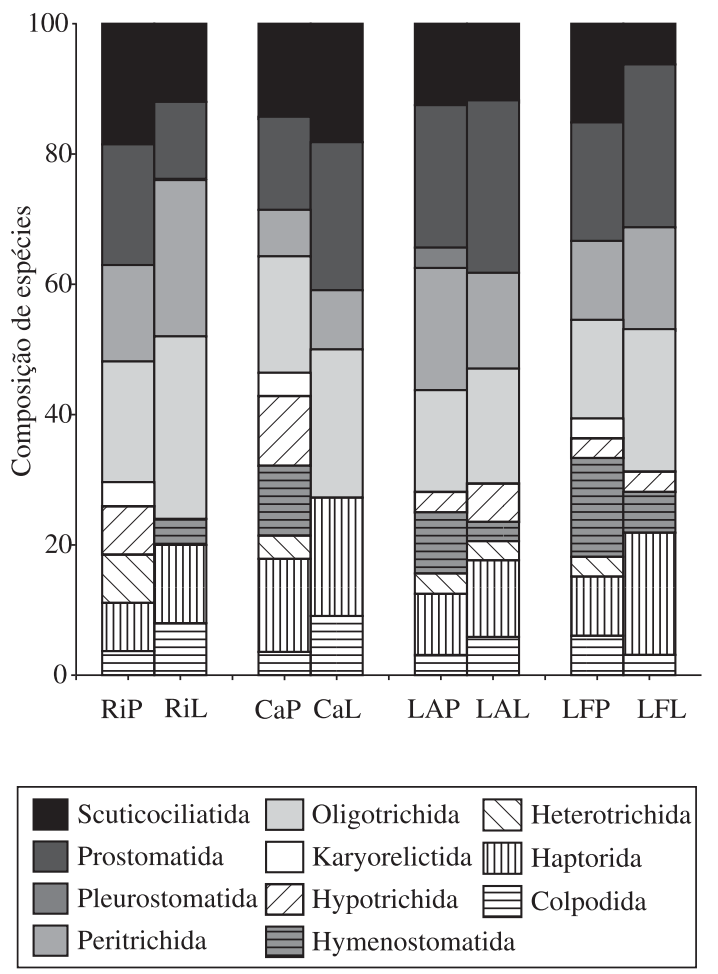

Figure 3. Percentage of the number of ciliates species per order verified in the different environment types and periods in the Upper Paraná River floodplain (Ri $\mathrm{P}=$ rivers potamophase; $\mathrm{RiL}=$ rivers limnophase $; \mathrm{ChP}=$ channels potamophase; $\mathrm{ChL}=$ channels limnophase OLP = open lakes potamophase $;$ OLL $=$ open lakes limnophase CLP $=$ closed lakes potamophase; $\mathrm{CLL}=$ closed lakes limnophase).

In general, Oligotrichida, Prostomatida and Haptorida were more speciose during the limnophase, whereas Hymenostomatida and Scuticociliatida tended to present a great number of species during the potamophase (see Table 1).

Among the 61 identified species, 21 are classified as pelagic while 40 are considered preferentially as littoral species. During the potamophase, in most of the environments, a higher number of littoral species in relation to pelagic ones was observed. On the other hand, during the limnophase, in general, there was a greater contribution of pelagic species (as shown in Table 1).

According to the frequency of occurrence, most species were recorded in a few samples of each environment and period, and they were considered as accidental. Among them, 14 (13 littoral species) were registered only in one environment type and during only one period (as shown in Table 1). On the other hand, pelagic species were more frequent than littoral ones mainly in the lakes during the limnophase (as shown in Table 1).

Eight species were registered in all environments and periods: Limnostrombidium sp., Rimostrombidium humile, $R$. lacustris and
Tintinnidium sp. (Oligotrichida), Balanium planctonicum, Urotricha farcta and Urotricha sp. (Prostomatida), and Cyclidium epitatricum (Scuticociliatida) (as shown in Table 1).

During the potamophase, only the prostamatids (U. farcta, in channels and open lakes, and Urotricha sp., in the channels) were considered as constant species (as shown in Table 1). On the other hand, during the limnophase, several species were classified as constant in the lakes, such as Codonella cratera, Limnostrombidium sp., Rimostrombidium humile, R. lacustris, Halteria grandinella and Tintinnidium sp. (Oligotrichida), Vorticella aquadulcis (Peritrichida), Urotricha farcta and Urotricha sp. (Prostomatida) and Cyclidium epitatricum (Scuticociliatida) (as shown in Table 1). The occurrence of Codonella cratera, Coleps hirtus and Enchelys sp. were only in the limnophase, and these species were classified as constant or frequent species (as shown in Table 1).

The turnover rate of the ciliates species composition between sampling periods, quantified by the Beta 1 index, in each environment type showed that greater changes in species composition were observed in the lotic environments, rivers $(75.6 \%)$, and channels $(66.7 \%)$, while lower changes were recorded in the open lakes $(53.1 \%)$.

A Cluster Analysis evidenced a higher dissimilarity of the ciliates species composition between periods (potamophase and limnophase) than among environment types (see Figure 4). In this way, the analysis discriminated two groups: the first one compounded by sampling units from the potamophase and the other from the limnophase (see Figure 4).

A Detrended Correspondence Analysis (DCA) corroborated the Cluster analysis evidencing a discrimination of the sampling sites under limnophase, negatively correlated with the axis 1 , from those sampling sites under potamophase, positively correlated to the same axis (see Figure 5a).

Through the scores distribution derived from the DCA, it was possible to observe that Holophrya discolor, Ctedoctema acanthocryptum, Coleps hirtus, Lagynophrya acuminata, Enchelys sp., Askenasia volvox, Codonella cratera, Actinobolina sp., Stokesia vernalis, Tintinnidium sp. and Urotricha sp., most of them typically pelagic, were negatively correlated with the axis 1 and determined the discrimination of the limnophase samples. On the other hand, Coleps elongatus, Tetrahymena pyriformis, Cyclidium glaucoma, Epistylis pygmaeum, Campanella umbellaria, Cyrtolophosis mucicola, Bursellopsis sp., Stichotricha aculeata, Calyptotricha lanuginosa and Vorticella campanula, most of them littoral species, were positively correlated with the same axis, characterizing the ciliates community composition during the potamophase (see Figure 5b).

The ANOVA results indicated significant differences between the scores from the sampling periods 


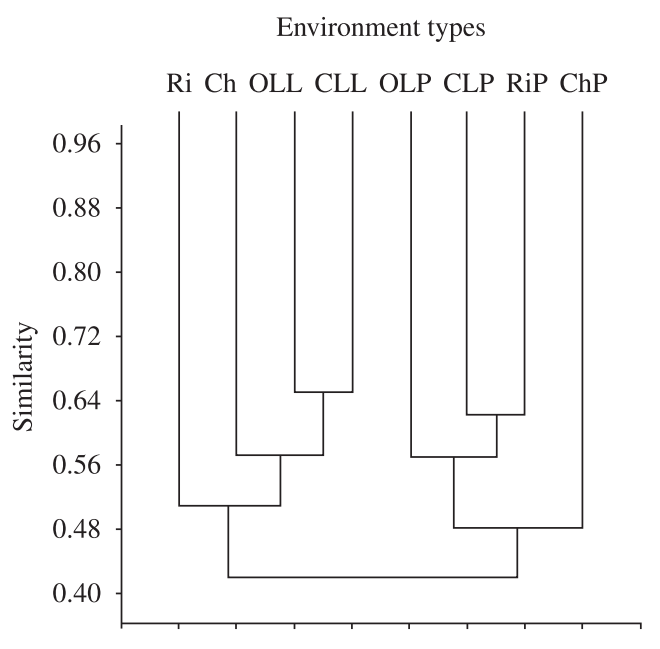

Figure 4. Cluster analysis based on the occurrence of plankton ciliate species in the different environment types from the Upper Paraná River floodplain (Cophenetic Correlation Coefficient $=0.82$; measurement $=$ discordance percentage; linkage method $=$ UPGA) $(\mathrm{RiL}=$ rivers limnophase $; \mathrm{ChL}=$ channels limnophase; OLL $=$ open lakes limnophase $; \mathrm{CLL}=$ closed lakes limnophase; $\mathrm{RiP}=$ rivers potamophase; $\mathrm{ChP}=$ channels potamophase; OLP = open lakes potamophase; CLP $=$ closed lakes potamophase) .

$(\mathrm{F}=23.87 ; \mathrm{p}=0.00007)$, whereas the differences among environmental types were not statistically significant $(F=0.683 ; p=0.567)$ (see Figure 6).

\section{Discussion}

The knowledge regarding the total diversity in an environment or ecosystem is strongly influenced by the sampling effort. However, the total number of species recorded in the present study (61 species) was higher than observed in other studies (Bossolan and Godinho, 2000; Wiackowski et al., 2001; Gomes and Godinho, 2003; Carrick, 2005; Cardoso, 2007), which registered between 17 and 36 ciliate species in plankton samples.

This great diversity recorded in the Upper Paraná River floodplain is due to the high connectivity among the compartments (littoral, benthic and pelagic) of the different environments, which determines the occurrence of non-planktonic species in the pelagic zone. This contribution of littoral species to the pelagic zone in this floodplain has been evidenced for other zooplanktonic groups, with significant occurrence of testate amoebae, rotifers and microcrustacean species coming from other compartments (Lansac-Tôha et al., 2009). Pfister et al. (2002) also demonstrated the importance of a high environmental heterogeneity to the pelagic ciliates diversity in 58 German lakes (140 species).

The structure of ciliate communities is strongly affected by physical, chemical and geomorphological characteristics (Madonni and Baghiroli, 2007). According to
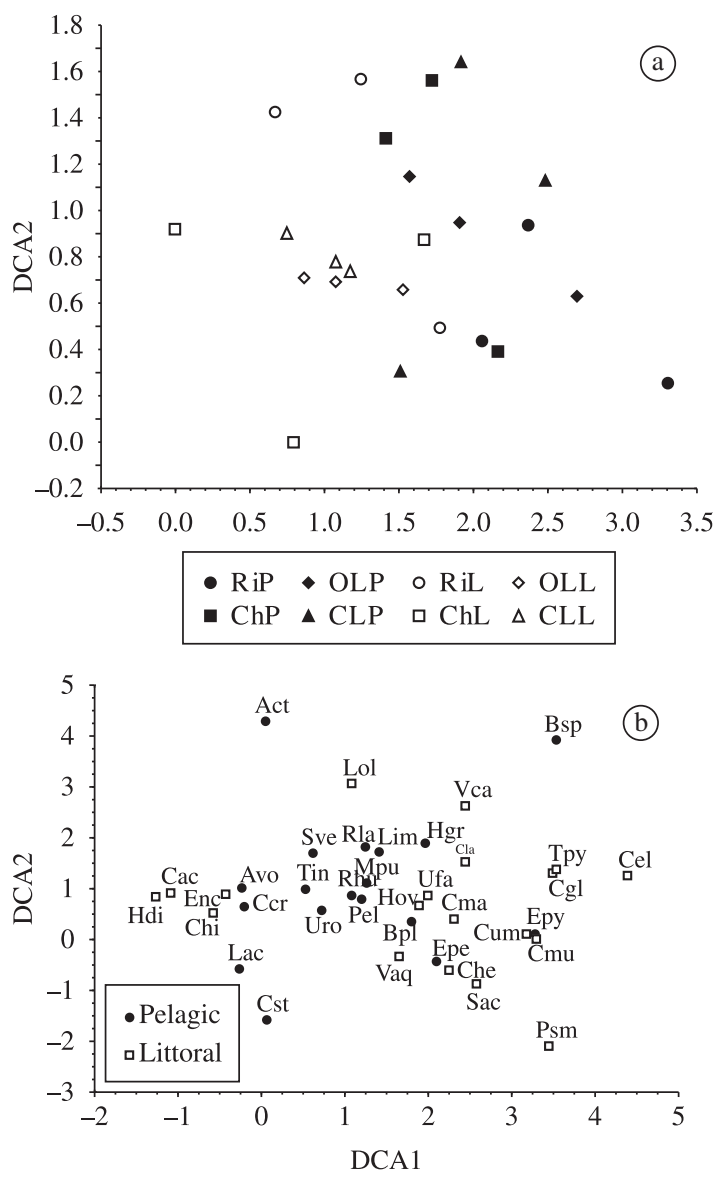

Figure 5. a) Scores distribution of samples and b) species along the DCA axes defined by ciliates composition in the Upper Paraná River floodplain. (RiL = rivers limnophase; $\mathrm{ChL}=$ channels limnophase $; \mathrm{OLL}=$ open lakes limnophase; $\mathrm{CLL}=$ closed lakes limnophase; $\mathrm{RiP}=$ rivers potamophase; $\mathrm{ChP}=$ channels potamophase OLP $=$ open lakes potamophase; CLP = closed lakes potamophase). Species codes are presented in the Table 1.

Andrushchshyn et al. (2003), in dynamic environments, abiotic factors are constantly changing and they are reflected in biotic changes such as species composition. In this way, a long-term monitoring study seems to be the most accurate method to register the real composition of ciliate procta, especially in an ecosystem with temporal dynamics as complex as the Upper Paraná River floodplain.

The difference between the observed species number (61 species) in relation to those estimated by the different non-parametric extrapolating indices (between 67 and 86 species) can be explained by the great number of non-pelagic species. In general, these species have a low frequency of occurrence, and these indices are based on the occurrence of rare species.

The higher number of exclusive species in the lakes, in relation to those registered only in the rivers and channels, seems to be related to the high stability of water 

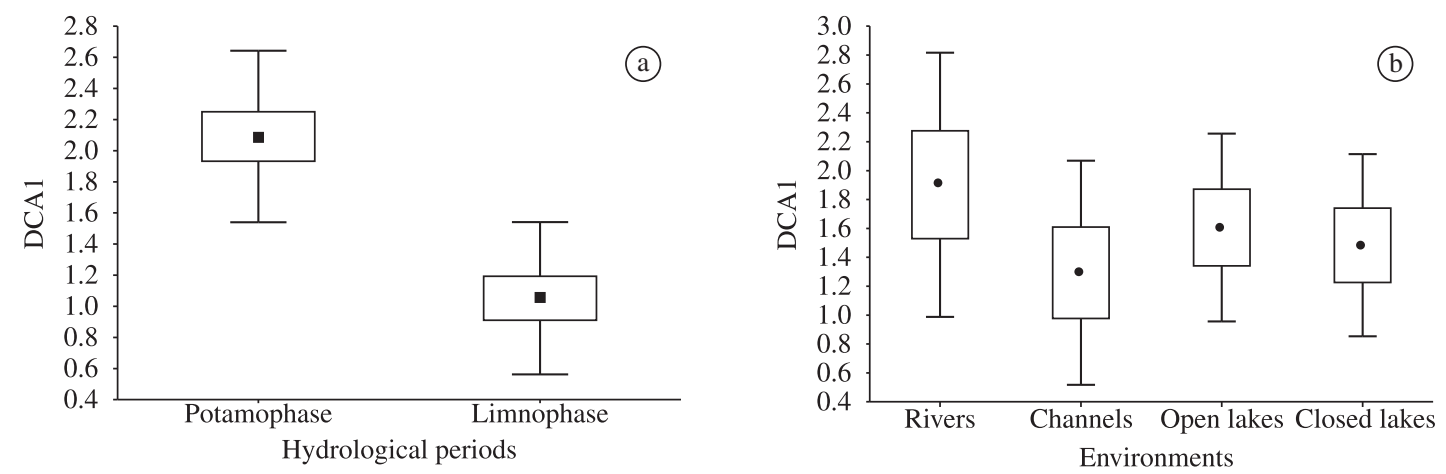

Figure 6. DCA scores from the ciliates composition in the a) sampling periods and b) environments from the Upper Paraná River floodplain ( $\mathbf{\square}=$ mean; $\square=$ standard error; $\mathrm{I}=$ standard deviation).

flow in lentic environments. Also, the higher influence of ciliates species associated with the littoral zone in the plankton compartment of lentic environments explains the higher number given the higher abundance of aquatic macrophytes in the lakes when compared to the rivers.

The predominance of Prostomatida and Oligotrichida orders in the Upper Paraná River floodplain was related to their pelagic habitat, and it also explain the improvement provided by their contribution in species number to the composition of ciliates during the limnophase period, when the compartment isolation and water column stability are more pronounced. Thus, this hydrological period would favor the occurrence of truly pelagic ciliates in the Upper Paraná River floodplain. Prostomatida and Oligotrichida also dominated the pelagic ciliate communities in 58 German lakes (Pfister et al., 2002). Zingel (2005) found these two orders in an Eastern European Lake, plus Haptorida, as the most important in the epilimnion.

Oligotrichida frequently compose the most diverse group of ciliates in the pelagic compartment (Müller et al., 1991; Song, 2000; Mieczan, 2007). The frequent presence of organisms from this order is due to their filtering feeding habit and their high adaptability to inhabiting the water column. Also, they do not need any substrate or other organisms for attachment, i.e., they are euplanktonic organisms (Fenchel, 1982).

On the other hand, the addition of the orders Hymenostomatida and Scuticociliatida, omnivores and even litter eater species, during the potamophase suggests the influence of the allochtonous organic matter to the protozoan communities. According to Scherwass et al. (2005), the particulate detritus is an important food resource for flagellates and ciliates.

In general, the high species richness from Prostomatida, Hymenostomatida and Peritrichida, especially represented by littoral species, as well as the typically pelagic order, Oligotrichida, in the Upper Paraná River floodplain, suggest a complex interaction between littoral organisms and those truly planktonic organisms in the pelagic zone. Indeed, littoral species were more speciose than pelagic ones. However, the pelagic species have higher frequencies of occurrence and, in general, their frequency was constant. These species are adapted to move, develop and reproduce in the water column, using resources produced in the pelagic zone, whereas the littoral species grow on a substrate in other compartments, which are not always present in the pelagic zone.

In this way, euplanktonic species are distributed more homogeneously in the pelagic zone of several of environments studied, while the littoral species have a more restricted distribution because they are occasionally carried to the water column. This fact can also explain the high importance of plankton species during the limnophase and the littoral species during the potamophase.

Among the species recorded in all environments and periods, there is a great number of Oligotrichida, corroborating the studies of Bossolan and Godinho (2000) and Kalinowska (2004), which documented Strombidium spp. (in the present study Limnostrombidium sp., Rimostrombidium humile and $R$. lacustris) as the most common species in the lakes studied. Furthermore, Müller et al. (1991) attribute the small Prostomatida (Urotricha and Balanion genera) as among the most important species in the studied lakes. Song (2000) considers Cyclidium spp. as the species reaching very high values of frequency in two Chinese lakes.

According to Zingel (2005), the Prostomatida Urotricha spp. present the same distribution pattern observed for the Oligotrichida in the Verevi Lake (East European), which is also the same taxon observed in the Upper Paraná River floodplain. The Urotricha spp. feed on algae and bacteria (Berger and Foissner, 2003) and are free or attached to allochtonous material, which explains why these are the only species frequent both during the potamophase and limnophase. In other words, apparently they are more adapted to the temporal changes in the floodplain. 
Beta diversity results showed great alterations in the species composition for all environment types determined by a great input of allochtonous species in the pelagic zone during the potamophase (see DCA results), when a great part of littoral region is flooded. However, this species turnover is slightly pronounced in lentic environments, suggesting that this input of allochtonous species, to a greater or lesser extent, is occurring throughout the hydrological period in the pelagic zone of the lakes.

One of the main discussions about the ecology of floodplains is related to the relative importance of the flood pulse (regional and temporal factor), and connectivity and hydrodynamics (spatial and local factors) on the structure of aquatic communities. In this way, some authors have attributed the flood pulse as the main factor structuring the distinct aquatic communities in the Upper Paraná River floodplain (Lima et al, 1998; Bonecker et al., 2005). On the other hand, some studies have suggested that the spatial heterogeneity in floodplain systems, including the differences in the hydrodynamic and connectivity, is an important factor on the communities' organization, more than the temporal changes determined by the flood pulse (Velho et al., 2004; Higuti et al., 2007).

In the present study, the results obtained regarding the planktonic ciliate community, in both Cluster and DCA analyses, revealed that ciliate species composition was significantly distinct between periods, while among environments with differing degrees of connectivity and hydrological characteristics differences in composition were not evident. In this way, the results demonstrated that the typically pelagic species characterized the ciliates community during the limnophase period while the littoral species were preponderant in the composition of ciliates during the potamophase period. In conclusion, our results strongly support the idea of the flood pulse as the main factor driving the composition pattern of the planktonic ciliates community in the Paraná River floodplain.

Acknowledgements - We thank to CNPq/ Peld and Nupelia/ UEM for financial and logistic support and Dr. Erica Mayumi Takahashi for suggestions and criticism.

\section{References}

ANDRUSHCHSHYN, O., MAGNUSSON, K. and WILLIAMS, DD., 2003. Ciliate populations in temporary freshwater ponds: seasonal dynamics and influential factors. Freshwater Biology, vol. 48 , no. 3 , p. $548-564$.

BERECZKY, M., 1998. Long-term ecological investigations of protozoan communities in the Danube River. Verhandlungen Internationale Vereinigung für Theoretische und Angewandte Limnologie, vol. 26, p. 978-982.

BERGER, H. and FOISSNER, W., 2003. Illustrated guide and ecological notes to ciliate indicator species (Protozoa, Ciliophora) in running water, lakes and sewage plants. In STEINBER, GC., CALMANO, W., KLAPPER, H. and WILKEN, RD. (Eds.). Handbuch Angewandte Limnologie, 17. Landsberg: Verlagsgesellschaft. p. 1-160.
BONECKER, CC., COSTA, CL., VELHO, LFM. and LANSACTÔHA, FA., 2005. Diversity and abundance of planktonic rotifers in different environments of the Upper Paraná River floodplain Paraná State - Mato Grosso do Sul State, Brazil. Hydrobiologia, vol. 546, p. 405-414

BOSSOLAN, NRS. and GODINHO, MJL., 2000. Abundância numérica e composição do protozooplâncton na lagoa do Infernão, SP. In SANTOS, JE. and PIRES, JSR. (Org.). Estudos integrados em ecossistemas: estação ecológica de Jataí. São Carlos: Editora RiMa. p. 523-536.

CARDOSO, L., 2007. Protozooplâncton e Rotifera. In BECKER, FG., RAMOS, RA. and MOURA, LA. (Eds.) Biodiverdidade das regiões da Lagoa do Casamento e dos Butiazais de Tapes, Planície Costeira do Rio Grande do Sul. Brasília: Ministério do Meio Ambiente. p. 130-143.

CARRICK, HJ., 2005. An under-appreciated component of the biodiversity in plankton communities: the role of protozoa in Lake Michigan (a case study). Hydrobiologia, vol. 551, p. $17-32$

COLWELL, RK., 2006. Estimates: statistical estimation of species richness and shared samples. Storrs: Copyright (or Edition) of the author. Version 8. Available from: <http://purl. aclc.org/estimates>. Access in: 17 de Maio de 2008.

FENCHEL, T., 1982. Protozoa ecology: biology of free-living phagotrophic protests. Madison: Science Tech. Publishers. $197 \mathrm{p}$

FOISSNER, W. and BERGER, H., 1996. A user-friendly guide to the ciliates (Protozoa, Ciliophora) commonly used by hydrobiologists as bioindicators in rivers, lakes and waste waters, with notes on their ecology. Freshwater Biology, vol. 35, p. $375-482$

FOISSNER, W., BERGER, H. and SCHAUMBURG, J., 1999. Identification and ecology of limnetic plankton ciliates. Munich: Bavarian State Office for Water Management. 793p.

FINLAY, BJ. and ESTEBAN, GF., 1998. Freshwater protozoa: biodiversity and ecological function. Biodiversity and Conservation, vol. 7, no. 9, p. 1163-1186.

GOMES, EAT. and GODINHO, MJL., 2003. Structure of the protozooplankton community in a tropical shallow and eutrophic lake in Brazil. Acta Oecologica, vol. 24, p. 153-161.

HARRISON, S., ROSS, SJ. and LAWTON, JH., 1992. Beta diversity on geographic gradients in Britain. Journal of Animal Ecology, vol. 61, no. 1, p. 151-158.

HIGUTI, J., VELHO, LFM., LANSAC-TÔHA, FA. and MARTENS, K., 2007. Pleuston communities are buffered from regional flood pulses: the example of ostracodes in the Paraná River floodplain, Brazil. Freshwater Biology, vol. 52, no. 10, p. 1930-1943.

HILL, MO. and GAUCH, HE., 2004. Detrended correspondence analysis: an improved ordination technique. Plant Ecology, vol. 42 , no. $1-3$, p. $47-58$.

JUNK, WJ., BAILEY, PB. and SPARKS, RE., 1989. The flood pulse concept in river-floodplain systems. Canadian Special Publication of Fisheries and Aquatic Sciences, vol. 106, p. 110-127.

KALINOWSKA, K., 2004. Bacteria, nanoflagellates and ciliates as components of the microbial loop in three lakes of 
different trophic status. Polish Journal of Ecology, vol. 52, no. 1, p. 19-34.

LANSAC-TÔHA, FA., BONECKER, CC., VELHO, LFM., SIMÕES, NR., DIAS, JD., ALVES, GM. and TAKAHASHI, EM., 2009. Biodiversity of zooplankton communities in the Upper Parana River floodplain: interannual variation from longterm studies. Revista Brasileira de Biologia = Brazilian Journal of Biology, vol. 69, no. (2 suppl), p. 661-668.

LIMA, AF., LANSAC-TÔHA, FA., VELHO, LFM. and BINI, LM., 1998. Environmental influence on planktonic cladocerans and copepodds in the floodplain of the upper river Paraná, Brazil. Studies on Neotropical Fauna and Environment, vol. 33, no. 4, p. 87-99.

MADONNI, P. and BRAGHIROLI, S., 2007. Changes in the ciliate assemblage along a fluvial system related to physical, chemical and geomorphological characteristics. European Journal of Protistology, vol. 43, no. 2, p. 67-75.

McCUNE, B. and MEFFORD, MJ., 1999.PC-ORD for Windows: multivariate analysis of ecological data. Gleneden Beach: MjM Software. Version 4.01.

MIECZAN, T., 2007. Size spectra and abundance of planktonic ciliates within various habitats in a macrophyte-dominates lake (Eastern Poland). Biologia Bratislava, vol. 62, no. 2, p. 189-194.

MÜLLER, H., SCHÖNE, A., PINTO-COELHO, RM., SCWEIZER, A. and WEISSE, T., 1991. Seasonal succession of ciliates in Lake Constance. Microbial Ecology, vol. 21, no. 1, p. 119-138.

NEIFF, JJ., 1990. Ideas para la interpretacion ecologica del Parana. Interciencia, vol. 15, no. 6, p. 424-439.

PFISTER, G., AUER, B. and ARNDT, H., 2002. Pelagic ciliates (Protozoa, Ciliophora) of different brackish and freshwater lake: a community analysis at the species level. Limnologica, vol. 32 , no. 2 , p. $147-168$.

PRIMC-HABDIJA, B., HABDIJA, I. and RADANOVIC, I., 1998. Seasonal changes in trophic structure of periphytic ciliates in relation to discharge regime. Verhandlungen-Internationale Vereinigung für Theoretische und Angewandte Limnologie, vol. 26, no. 3, p. 1116-1119.

SCHERWASS, A., FISCHER, Y. and ARNDT, H., 2005. Detritus as a potential food source for protozoans: utilization of fine particulate plant detritus by a heterotrophic flagellate,
Chilomonas paramecium, and a ciliate, Tetrahymena pyriformis. Aquatic Ecology, vol. 39, no. 4, p. 439-445.

SCHWEIZER, A., 1997. From littoral to pelagial: comparing the distribution of phytoplankton and ciliated protozoa along a transect. Journal of Plankton Research, vol. 19, no. 7, p. 829-848.

SONG, B., 2000. A comparative study on planktonic ciliates in two shallow mesotrophic lakes (China): species composition, distribution and quantitative importance. Hydrobiologia, vol. 427, p. 143-153.

STATSOFT INCORPORATION, 2000. STATISTICA for Windows. VERSION 7.1. Tulsa: STATSOFT INC.

THOMAZ, SM., ROBERTO, MC., LANSAC-TÔHA, FA., ESTEVES, FA. and LIMA, AF., 1991. Dinâmica temporal dos principais fatores limnológicos do rio Baía: planície de inundação do alto rio Paraná-MS, Brasil. Revista UNIMAR, vol. 13 , no. 2, p. 299-312.

THOMAZ, SM., ROBERTO, MC., LANSAC-TÔHA, FA., ESTEVES, FA. and LIMA, AF., 1992. Características limnológicas de uma estação de amostragem do alto rio Paraná e outra do baixo rio Ivinheima (PR-MS, Brasil). Acta Limnologica Brasiliensia, vol. 4, no. 1, p. 32-52.

VELHO, LFM., BINI, LM. and LANSAC-TÔHA, FA., 2004. Testate amoeba (Rhizopoda) diversity in plankton of the Upper Paraná River Floodplain, Brazil. Hydrobiologia, vol. 523, p. 103-111.

VELHO, LFM., PEREIRA, DG., PAGIORO, TA., SANTOS, VD., PERENHA, MCZ. and LANSAC-TÔHA, FA., 2005. Abundance, biomass and size structure of planktonic ciliates in reservois with distinct trophic states. Acta Limnologica Brasiliensia, vol. 17, no. 4, p. 361-371.

WARD, JV., TOCKNER, K. and SCHIEMER, F., 1999. Biodiversity of floodplain river ecosystems: ecotones and connectivity. Regulated Rivers Research and Management, vol. 15, p. 125-139.

WIACKOWSKI, K., VENTELÄ, A., MOILANEN, M., SAARIKARI, V., VUORIO, K. and SARVALA, J., 2001. What factors control planktonic ciliates during summer in a highly eutrophic lake?. Hydrobiologia, vol. 443, p. 43-57.

ZINGEL, P., 2005. Vertical and seasonal dynamics of planktonic ciliates in a strongly stratified hypertrophic lake. Hydrobiologia, vol. 547, p. 163-174. 